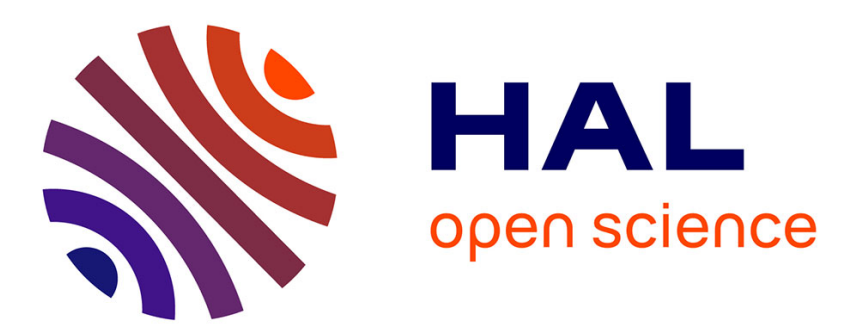

\title{
Fine-scale simulations of aeolian sediment dispersion in a small area in the northern Chihuahuan Desert
}

George E Bowker, Dale A Gillette, Gilles Bergametti, Beatrice Marticorena, David K Heist

\section{- To cite this version:}

George E Bowker, Dale A Gillette, Gilles Bergametti, Beatrice Marticorena, David K Heist. Fine-scale simulations of aeolian sediment dispersion in a small area in the northern Chihuahuan Desert. Journal of Geophysical Research, 2008, 113 (F2), 10.1029/2007JF000748 . hal-02326123

\section{HAL Id: hal-02326123 \\ https://hal.science/hal-02326123}

Submitted on 22 Oct 2019

HAL is a multi-disciplinary open access archive for the deposit and dissemination of scientific research documents, whether they are published or not. The documents may come from teaching and research institutions in France or abroad, or from public or private research centers.
L'archive ouverte pluridisciplinaire HAL, est destinée au dépôt et à la diffusion de documents scientifiques de niveau recherche, publiés ou non, émanant des établissements d'enseignement et de recherche français ou étrangers, des laboratoires publics ou privés. 


\title{
Fine-scale simulations of aeolian sediment dispersion in a small area in the northern Chihuahuan Desert
}

\author{
George E. Bowker, ${ }^{1,2}$ Dale A. Gillette, ${ }^{3}$ Gilles Bergametti, ${ }^{4}$ Béatrice Marticorena, ${ }^{4}$ \\ and David K. Heist ${ }^{3}$ \\ Received 8 January 2007; revised 19 May 2007; accepted 7 August 2007; published 1 March 2008.
}

[1] The northern Chihuahuan Desert in New Mexico contains mesquite bushes and small coppice dunes as well as open areas lacking vegetation. Sandstorms are common in this area, gradually reshaping the flat grassland into a landscape of mesquite coppice dunes and bare open patches. During storms, complex airflows entrain sediment from the open areas, depositing it around downwind bushes and dunes. Understanding and quantifying these processes could help to clarify the ongoing process of desert formation. Sand flux patterns for eight storms occurring in April 2003 and April 2004 were predicted for a $(60 \mathrm{~m}$ by $60 \mathrm{~m})$ site on the basis of 29710 -min average velocity simulations using a semiempirical mass consistent diagnostic wind field model: Quick Urban \& Industrial Complex version 3.5 (QUIC) used with a sand flux parameterization. The sand flux patterns were highly heterogeneous, varying with wind direction and differing between storms. Generally, the nonvegetated areas experienced high sand fluxes, while wake areas behind dunes experienced little or no sand flux. Sediment erosion and deposition patterns were calculated by taking the divergence of the sand flux. The open areas were the sources of the sediment, while the windward sides of the mesquite bushes and dunes were the primary deposition areas. The simulated sediment erosion and deposition magnitudes were qualitatively similar to an annual average from 45 years of measurements.

Citation: Bowker, G. E., D. A. Gillette, G. Bergametti, B. Marticorena, and D. K. Heist (2008), Fine-scale simulations of aeolian sediment dispersion in a small area in the northern Chihuahuan Desert, J. Geophys. Res., 113, F02S11, doi:10.1029/2007JF000748.

\section{Introduction}

[2] Sandstorms are common throughout the desert regions of the southwestern United States. During a sandstorm, the wind entrains large particles of sand or other coarse particulate $(>100 \mu \mathrm{m}$ in size), carrying them for short distances (on the order of $1 \mathrm{~m}$ ) before they return to the surface, sandblasting the ground [Bagnold, 1941]. This initiates a positive feedback cascade, creating more airborne sediment. The sandblasting during windstorms produces fine particulate aerosol (dust) as the finer material is freed from larger aggregates [Gillette, 1981]. Dust emission during sandstorms is a significant contributing element in the global atmospheric aerosol mass balance and could affect planetary albedo, and by consequence, the climate

\footnotetext{
${ }^{1}$ Atmospheric Modeling Division, National Exposure Research Laboratory, U.S. Environmental Protection Agency, Research Triangle Park, North Carolina, USA.

${ }^{2}$ Now at Clean Air Markets Division, U.S. Environmental Protection Agency, Washington, DC, USA.

${ }^{3}$ Atmospheric Science Modeling Division, Air Resources Laboratory, National Oceanic and Atmospheric Administration, Research Triangle Park, North Carolina, USA.

${ }^{4}$ UMR 7583, Laboratoire Interuniversitaire des Systèmes Atmosphériques, CNRS, Universités Paris 7-Paris 12, Créteil, France.

Copyright 2008 by the American Geophysical Union. 0148-0227/08/2007JF000748\$09.00
}

[Andreae, 1996]. The focus of this article is not to consider the production and transport of dust and finer particles $(<50 \mu \mathrm{m})$, but rather, to explore the patterns and magnitudes of wind-driven movement of sand that produces fine dust in areas with complex roughness elements (e.g., vegetation).

[3] Wind-based sediment erosion is influenced by meteorological conditions, distribution and composition of the overlying vegetation, and the geochemistry of the soil [Schlesinger et al., 1990; Okin and Gillette, 2001; Okin et al., 2006]. Vegetation influences sediment erosion by directly limiting the bare area available to be eroded, and by decreasing wind velocities and sheltering bare areas downwind. It would be desirable to model sediment erosion, transport, and deposition in such complex environments to understand the local effects of small-scale wind patterns on the larger process of desert formation and the production of dust aerosols at a regional and global level [Okin et al., 2006]. In particular, variability in sediment transport is related to the patterns of wind acceleration, deceleration, and sheltering. Using this information, it would be possible to explore the interrelationships between fine-scale flow patterns, dune formation, and the distribution of vegetation within the desert.

[4] In the Jornada Experimental Range (JER) located in the northern Chihuahuan Desert in the southern region of New Mexico, wind processes affect the shape of the 
Table 1. Spatially Averaged Sand Flux Per Storm for Locations Within the "Focus" Area as Well as Percent Area Experiencing Various Levels of Flux Divergence ${ }^{\mathrm{a}}$

\begin{tabular}{|c|c|c|c|c|c|c|c|c|c|}
\hline & \multirow{2}{*}{$\begin{array}{l}\text { Gibbens et al. }[1983] \\
\text { Yearly Average }\end{array}$} & \multicolumn{5}{|c|}{ QUIC Model 2003} & \multicolumn{3}{|c|}{ QUIC Model 2004} \\
\hline & & Storm 1 & Storm 2 & Storm 3 & Storm 4 & Storm 5 & Storm 1 & Storm 2 & Storm 3 \\
\hline $\begin{array}{l}\text { Spatial average of total flux, } \mathrm{g} \mathrm{cm}^{-1} \\
\text { for the course of a storm }\end{array}$ & & 55.4 & 14.9 & 371.2 & 10.2 & 139.0 & 0.0 & 10.3 & 22.0 \\
\hline Locations with no flux divergence, $\%$ & 0 & 45 & 58 & 34 & 51 & 35 & 99 & 54 & 37 \\
\hline Erosion locations, \% & 70 & 25 & 19 & 29 & 20 & 27 & 1 & 21 & 26 \\
\hline Deposition locations, \% & 30 & 30 & 23 & 37 & 28 & 38 & 1 & 25 & 37 \\
\hline
\end{tabular}

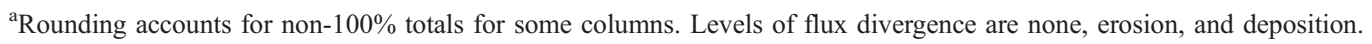

landscape. The area, once relatively flat grassland, is now dominated by mesquite bushes (Prosopis glandulosa) and coppice dunes, comprising mesquite bushes incorporated into and anchoring the sand dunes. The coppice dunes at the JER, which range in height up to about $3 \mathrm{~m}$, have formed over the past 70 years. The region is highly heterogeneous with about $25 \%$ vegetation and dune coverage. The coppice dunes are separated by elongated vegetation-free sandy soil patches, or "streets." The JER experiences strong windstorms with sediment erosion during the spring, with April often being the peak month [Gibbens et al., 1983; Gillette and Pitchford, 2004]. The dunes and the open areas are both oriented along the dominant wind direction: southwestnortheast [Okin and Gillette, 2001].

[5] Long-term measurements of dune formation and soil level change were made in the JER (as it changed from relatively flat open land, to mesquite dune lands) by marking the changing level of the soil at a 45-year interval on long steel rods driven into the ground at regular intervals along a linear transect. The average rate of soil "lowering" over 45 years (for locations being eroded, about $70 \%$ of the area derived from the frequency of locations experiencing erosion along the linear transect) was at least $0.21 \mathrm{~cm}$ per year $(\mathrm{n}=19)$ [Gibbens et al., 1983] (Tables 1 and 2). In areas of deposition (about 30\% of the area), the soil level increased an average of $0.24 \mathrm{~cm}$ per year $(\mathrm{n}=8)$ [Gibbens et al., 1983] (Tables 1 and 2).

[6] Over the past 6 years, sand movement and airflow patterns were measured within a small region $\left(3600 \mathrm{~m}^{2}\right)$ called "oriented," or MNORT, within the JER (Figure 1) [Gillette et al., 2006]. Approximately $25 \%$ of the "oriented" site is occupied by mesquite bushes and coppice dunes - essentially the same proportion found in the nearby area by Gibbens et al. [1983]. In this article, we intend to link sand fluxes with soil level changes for individual storms from 2 years differing in frequency and intensity of significant storms. We will qualitatively compare the simulated floor erosion/deposition averages with those presented by
Gibbens et al. [1983]. 2003 was an intensive storm year, with one storm (on 15 April, called storm 3 here) being one of the strongest in the last 10 years. Conversely, the second year examined, 2004, had relatively weak and infrequent storms.

[7] For the "oriented" site, the sand movement and airflow patterns have a high degree of spatial heterogeneity that vary with changes in wind measured at a height of $14.9 \mathrm{~m}$ above the surface [Gillette et al., 2006]. Within the domain, the highest velocities and fluxes are usually found in the streets. Bowker et al. [2006] used the semiempirical mass-consistent diagnostic time-averaged wind field and dispersion model Quick Urban \& Industrial Complex (QUIC, version 3.5) to simulate the airflow patterns at $25 \mathrm{~cm}$ and 10-min resolution for several intense sandstorms that occurred in April 2003, comparing the results to Gillette et al. [2006] velocity measurements. QUIC is being developed by the Los Alamos National Laboratory and the University of Utah on the basis of the Röckle approach [Röckle, 1990; Pardyjak and Brown, 2001, 2002, 2003; Pardyjak et al., 2004; Williams et al., 2004]. Like computational fluid dynamic (CFD) codes, QUIC simulates highly resolved flow and dispersion fields for complex geometries. However, unlike CFD which often uses time-intensive iterative techniques to solve Reynolds-averaged versions of the Navier-Stokes equations, QUIC takes a simple input velocity gradient and then applies empirical (wind tunnel) parameterizations for the basic flow patterns around simple obstacles (e.g., rectangular and cylindrical blocks) to each of the elements in the complex domain [Pardyjak and Brown, 2003]. For example, parameterizations describe the length of the recirculation cavities upwind [Hosker, 1984] and downwind [Fackrell, 1984] of the obstacle on the basis of its geometry. If the elements are close enough together, the parameterizations are adjusted to account for the direct interaction of the wake zones and creation of "street canyon" vortices [Pardyjak and Brown, 2003]. Mass conservation is then imposed over the entire simulated domain to produce the final flow field. Within QUIC, the

Table 2. Spatially Averaged Divergence of the Sand Flux and Change in Surface Height for Each Storm for Locations Within the "Focus" Area Experiencing Erosion and Deposition

\begin{tabular}{|c|c|c|c|c|c|c|c|c|c|}
\hline & \multirow{2}{*}{$\begin{array}{l}\text { Gibbens et al. }[1983] \\
\text { Yearly Average }\end{array}$} & \multicolumn{5}{|c|}{ QUIC Model 2003} & \multicolumn{3}{|c|}{ QUIC Model 2004} \\
\hline & & Storm 1 & Storm 2 & Storm 3 & Storm 4 & Storm 5 & Storm 1 & Storm 2 & Storm 3 \\
\hline \multicolumn{10}{|c|}{ Erosion } \\
\hline $\begin{array}{l}\text { Spatial average of flux divergence, } \\
\mathrm{g} \mathrm{cm}^{-2} \text {, standard deviation }\end{array}$ & & $\begin{array}{c}0.54 \\
(1.72)\end{array}$ & $\begin{array}{l}0.22 \\
(0.66)\end{array}$ & $\begin{array}{c}1.39 \\
(3.23)\end{array}$ & $\begin{array}{c}0.19 \\
(0.55)\end{array}$ & $\begin{array}{c}0.77 \\
(1.80)\end{array}$ & $\begin{array}{c}0.07 \\
(0.08)\end{array}$ & $\begin{array}{l}0.16 \\
(0.45)\end{array}$ & $\begin{array}{c}0.23 \\
(0.67)\end{array}$ \\
\hline Average sediment height change, $\mathrm{cm}$ & -0.21 & -0.34 & -0.14 & -0.87 & -0.12 & -0.48 & -0.04 & -0.10 & -0.14 \\
\hline \multicolumn{10}{|c|}{ Deposition } \\
\hline $\begin{array}{l}\text { Spatial average of flux convergence, } \\
\mathrm{g} \mathrm{cm}^{-2} \text {, standard deviation }\end{array}$ & & $\begin{array}{l}-0.46 \\
(1.21)\end{array}$ & $\begin{array}{l}-0.18 \\
(0.49)\end{array}$ & $\begin{array}{l}-1.29 \\
(2.47)\end{array}$ & $\begin{array}{l}-0.14 \\
(0.33)\end{array}$ & $\begin{array}{l}-0.61 \\
(1.24)\end{array}$ & $\begin{array}{l}-0.06 \\
(0.08)\end{array}$ & $\begin{array}{l}-0.13 \\
(0.32)\end{array}$ & $\begin{array}{l}-0.16 \\
(0.40)\end{array}$ \\
\hline Average sediment height change, $\mathrm{cm}$ & 0.24 & 0.29 & 0.11 & 0.81 & 0.09 & 0.39 & 0.04 & 0.08 & 0.10 \\
\hline
\end{tabular}


setup process, where the domain, spatial resolution, and geometry of the obstacles are specified is quite fast (a few minutes), and the final wind field calculation process takes a very short period of time (seconds to minutes). Compared with CFD, these attributes make the QUIC model efficient to use, allowing great flexibility in the number and kinds of simulations that can be made.

[8] For the "oriented" desert study site, the results from both the field study velocity measurements and the corresponding QUIC model simulations [Gillette et al., 2006; Bowker et al., 2006] suggest that the wind interacts with the dune landscape, resulting in complex airflow patterns. Since wind is the transporter and the source of the energy used to dislodge the sediments (through the sandblasting mechanism described by Gillette [1981]), the flow patterns are intimately tied to aeolian sediment transport. Bowker et al. [2007] predicted airborne sediment fluxes at point locations by using the QUIC velocity simulations with each of two sand flux parameterizations [Owen, 1964; Kawamura, 1964]. After integrating the flux over the course of a storm, the QUIC simulations were compared with field measurements of sand flux at 19 and 46 locations (for 2003 and 2004, respectively) within the domain and found to agree within $50 \%$ for most locations. Time-integrated flux comparisons were made for eight storms which varied in intensity and duration. Simulated 10-min average sand flux and corresponding measured 10-min time-averaged sand impacts from a Sensit instrument were correlated temporally and spatially [Bowker et al., 2007]. (Sensit is a trademark of Sensit Co., RR 1 Box 38, Portland, North Dakota 58274, www.sensit.com. Mention of trade names or commercial products does not constitute endorsement or recommendation for use by the United States Government.) Consequently, the results suggested that QUIC velocity fields could be used with a sand flux parameterization to predict sand flux patterns at high spatial and temporal resolution for a domain.

[9] In the present study, we use this technique to examine sand flux at grid points across the entire "oriented" domain, allowing us to understand the patterns of sand erosion, movement, and deposition in order to ultimately predict dune formation. The goals of this study are threefold:

[10] 1. To calculate the flux of sand at regularly spaced grid points throughout the domain for each 10-min time period for the duration of the eight sandstorms. We will show the pattern of sand flux in the domain is heterogeneous and that sand flux is high in areas with high velocities (e.g., the streets) while areas with low velocities correlate with regions of low sand movement.

[11] 2. To calculate the divergence of the flux, or sedimentation rate, at each grid cell location within the domain. Essentially, we will calculate the net sand flux entering and leaving each grid cell within the domain. Areas of erosion are locations where there is a divergence of flux of sand. Areas of deposition are locations where there is a convergence of flux. Furthermore, we will examine how the patterns and intensity of sand flux in the domain vary with the speed and direction of the approaching wind (measured at $14.9 \mathrm{~m})$.

[12] 3. To compute the net average height change of the desert surface due to erosion and deposition for each of the individual sand storms from the seasonal intensive storm period (during April 2003 and 2004) on the basis of timeintegrated calculations of the sedimentation rate for selected areas of the domain. We will qualitatively compare these values with measurements of 45-year means of soil surface height change due to wind erosion.

\section{Materials and Methods}

[13] QUIC simulations for 297 10-min periods were made for eight sand storms observed in April 2003 and April 2004 on the basis of $10-$ min time averaged wind velocity, $U_{\text {ref, }}$, measurements at the onsite $14.9 \mathrm{~m}$ meteorological tower (Figures 1 and 2) [Bowker et al., 2006, 2007; Gillette et al., 2006]. We assume that the input boundary layer is logarithmic and that $U_{\text {ref }}$ is steady and that the resulting wind patterns (and thus, the fluxes) have also reached equilibrium. 10-min averages were used because they represent a compromise between ignoring low-frequency contributions and errors caused by aliasing of the mean 10-min wind speed.

[14] The domain area (66 $\mathrm{m}$ by $66 \mathrm{~m}$ by $5 \mathrm{~m}$ ), including the mesquite bushes and coppice dunes, as measured in the field and as simulated within QUIC, are shown in Figure 1. Details of the domain and model setup are reported by Bowker et al. [2006, 2007]. The entire study domain was modeled in QUIC as a regular grid comprising $25 \mathrm{~cm}$ cubical cells. Mesquite bushes and dunes were modeled, to $25 \mathrm{~cm}$ resolution, as assemblies of solid cylinders and rectangular blocks. These blocks have completely vertical faces and flat horizontal top surfaces. They fully occupy grid cells in which they are present. The lateral $(x, y)$ dimensions and locations of the bushes and dunes were measured by Gillette and Pitchford [2004], while the average heights of the mesquite bushes and dunes were estimated from photographs and onsite observations. The rounded nature of the bushes and dunes, with sloping sides and rounded tops, was not modeled. Similarly, the open porous nature of the mesquite bushes, which, in nature, allows wind to pass through the plant, was not modeled. Except where mesquite bushes and dunes project from the surface, we assumed that the terrain is flat and coplanar with a height of zero.

[15] The input boundary layer used in these simulations was logarithmic,

$$
\mathrm{U}(\mathrm{z})=\frac{U *}{\kappa} \ln \left(\frac{\mathrm{z}-\mathrm{d}}{\mathrm{z}_{0}}\right),
$$

where $\kappa$ is Von Karman's constant (nominally taken to be $0.4), U(z)$ is the wind speed $\left(\mathrm{m} \mathrm{s}^{-1}\right)$ as a function of height $(\mathrm{z}, \mathrm{m}), U_{*}$ is the friction velocity $\left(\mathrm{m} \mathrm{s}^{-1}\right), \mathrm{z}_{0}$ is the roughness length $(\mathrm{m})$, and $\mathrm{d}(\mathrm{m})$ is the aerodynamic displacement height [Priestly, 1959]. For these simulations, we assume that $\mathrm{d}$ is zero. The input boundary layer was specified using the reference velocity, $\mathrm{U}_{\text {ref }}$, for each 10-min time period at the tower height of $14.9 \mathrm{~m}$.

[16] The roughness length $\left(\mathrm{z}_{0}\right)$ was adjusted by Bowker et al. [2006] to a value of $1.7 \mathrm{~cm}$. This was done by finding the average of the median roughness lengths necessary optimize the resulting velocity comparisons from two heights in QUIC (63 cm and $87 \mathrm{~cm})$ with measurements 

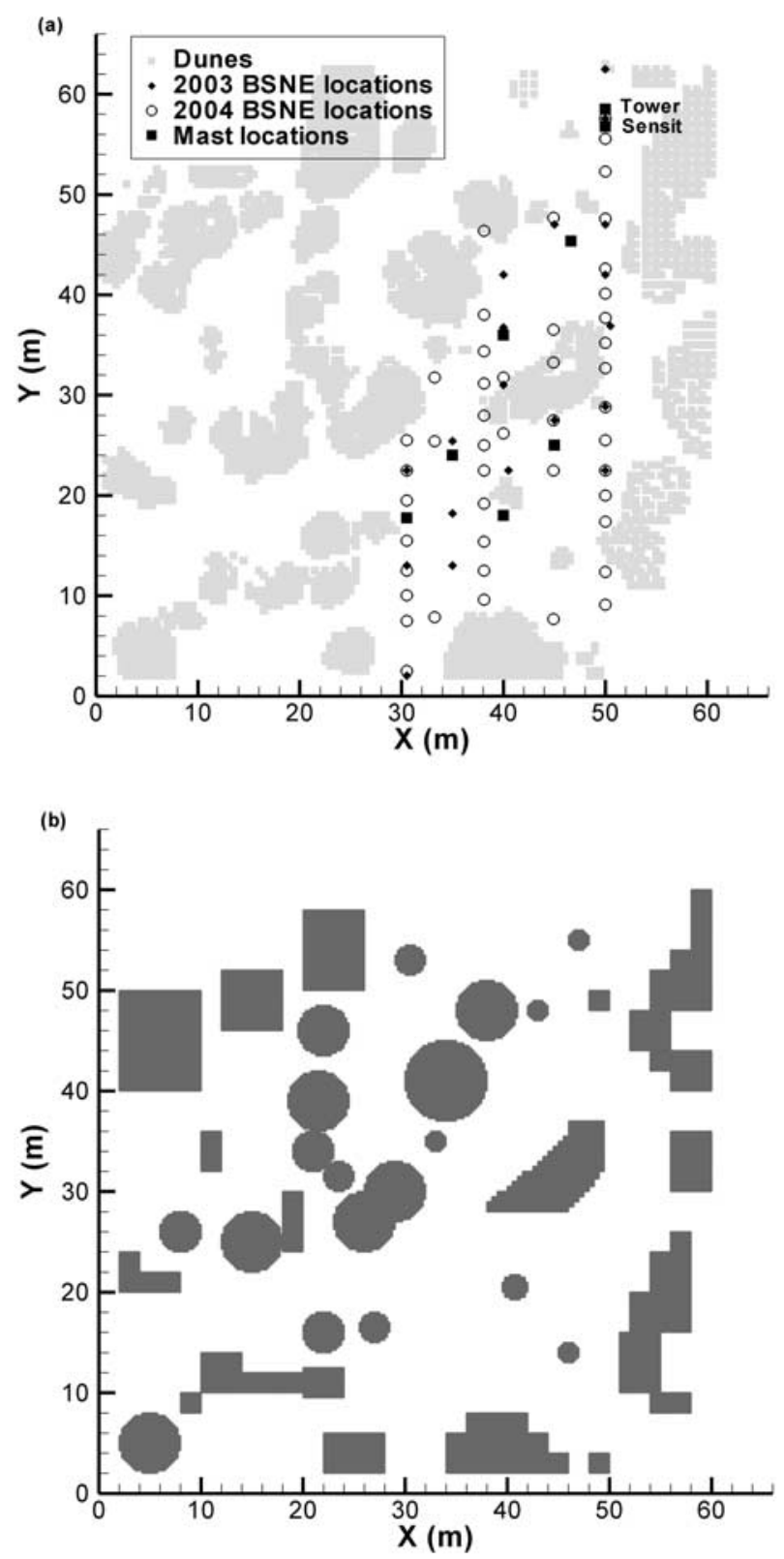

Figure 1. (a) Overhead representations of the study site in the field. The mesquite bushes and coppice dunes are shown in light gray. Sand flux measurement locations using Big Spring number eight (BSNE) sediment collectors are shown as open circles (2004) and black diamonds (2003). Masts, including the $14.9 \mathrm{~m}$ tower (labeled "Tower") where wind velocity measurements were made are shown as black squares. (b) Overhead representations of the study site in QUIC. The mesquite bushes and coppice dunes are shown as black squares.

made by Gillette et al. [2006] at the field study site at a height of $75 \mathrm{~cm}$.

[17] Three dimensional velocities were predicted by QUIC at the centerpoint of each cubical grid cell for the entire domain. Velocities within the bushes and dunes were automatically zero. For this study, we used only the horizontal velocity components of one horizontal plane of grid cells (from 50 to $75 \mathrm{~cm}$ above the surface, with a center point at $63 \mathrm{~cm}$ ). On the basis of the method developed by Bowker et al. [2007], each of these velocities was used with a sand flux parameterization to model the total vertically and time-integrated sand flux $\left(\mathrm{g} \mathrm{cm}^{-1}\right)$ at that location. The flux of sand is modeled as the amount of sand passing through a thin vertical strip, $1 \mathrm{~cm}$ wide and extending in height to $1 \mathrm{~m}$.

[18] The sand flux simulations were made using the parameterization developed by Kawamura [1951, 1964]. This parameterization has been used by a number of researchers including White [1979], Marticorena and Bergametti [1995], Marticorena et al. [1997], and Bowker et al. [2007]. Bowker et al. [2007] found the difference in sand flux predictions between the Kawamura [1964] and the Owen [1964] formulations of the sand flux equation was less than $10 \%$, and even less for high-flux conditions. The Kawamura sand flux parameterization predicts the total horizontal flux of sand, $q$, at each point (vertically integrated with height), for each time period on the basis of the friction velocity $\left(U_{*}\right)$ and threshold friction velocity $\left(U_{*}\right)$, the friction velocity where sand first begins to move:

$$
q=a_{1} \frac{\rho}{g}\left(U_{*}-U_{*_{t}}\right)\left(U_{*}+U_{*_{t}}\right)^{2},
$$

where $\rho$ is the density of air, $g$ is the acceleration of gravity, and $a_{1}$ is a constant adjusting the equation to the specific location.

[19] For these simulations, we assume that the velocity at a given height at each $x, y$ location within the domain is directly proportional to the friction velocity at that location, and that the proportionality constant, $b$, is invariant across the domain:

$$
U_{*}=U(\mathrm{z})^{*} b
$$

where $U(\mathrm{z})$ is the wind speed measured at a height $(\mathrm{z})$ of $63 \mathrm{~cm}$. For example, in the streets, where the flow is unobstructed, the proportionality constant can be derived from the logarithmic law (equation (1)). Similarly, using equation (3), a threshold velocity $\left(U_{\mathrm{t}}\right.$ at $\left.63 \mathrm{~cm}\right)$ where sand first begins to move can be found on the basis of $U_{*}$.

[20] Replacing the two friction velocities in equation (2) with the velocity values at $63 \mathrm{~cm}$ and combining the $a_{1}$ constant with the proportionality constant from equation (3) into a new constant, $c_{1}$,

$$
q=c_{1} \frac{\rho}{g}\left(U-U_{t}\right)\left(U+U_{t}\right)^{2}
$$

For this site and measurement height, Bowker et al. [2007] found that the constant $c_{1} \frac{\rho}{g}$ was $0.011 \mathrm{~g} \mathrm{~s}^{2} \mathrm{~m}^{-4}$ and the $U_{t}$ constant was $5.8 \mathrm{~m} \mathrm{~s}^{-1}$. These values were found by optimizing the fit between the net vertically integrated flux measured at particular locations in the field over the course of a storm [Gillette et al., 2006] with the simulated flux (integrated over all 10-min time periods within the storm) using equation (4) and the wind speeds predicted by QUIC at $63 \mathrm{~cm}$ at those locations.

[21] In this article, this technique is extended to simulate vertically integrated sand flux at every location throughout 


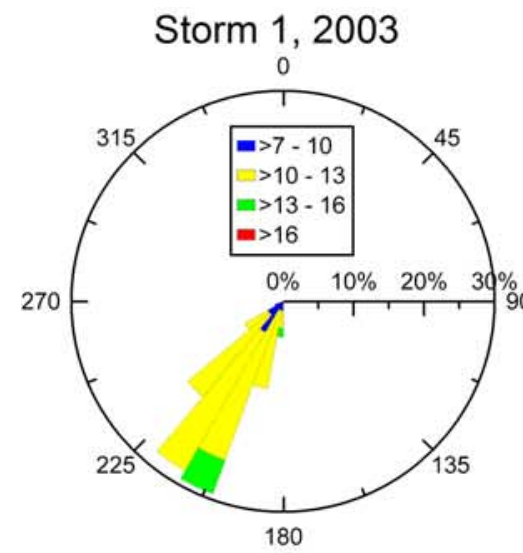

Storm 3, 2003

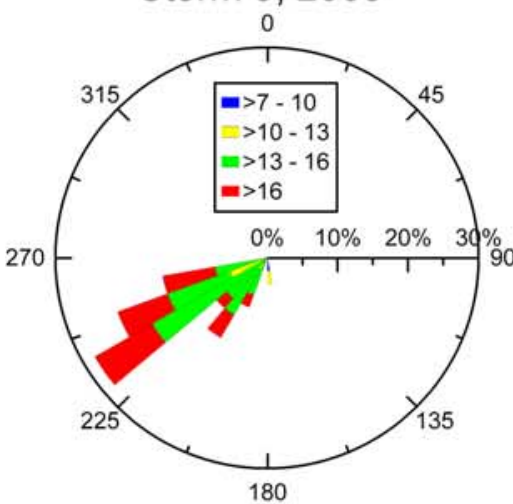

Storm 5, 2003

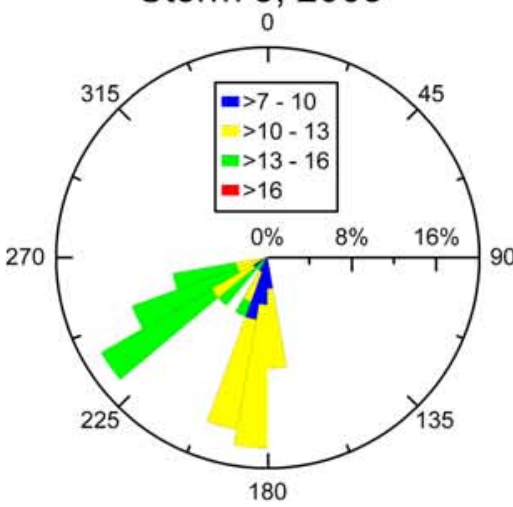

Storm 2, 2004

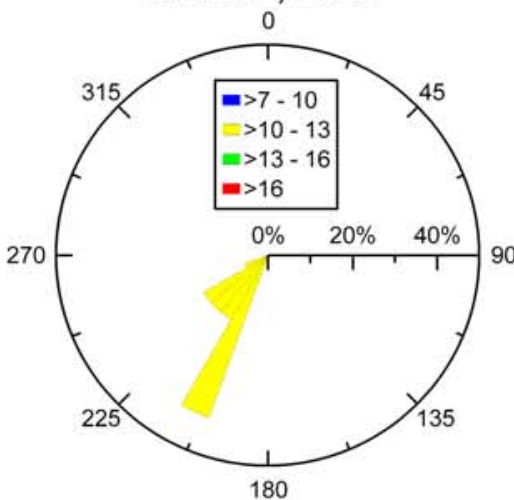

Storm 2, 2003

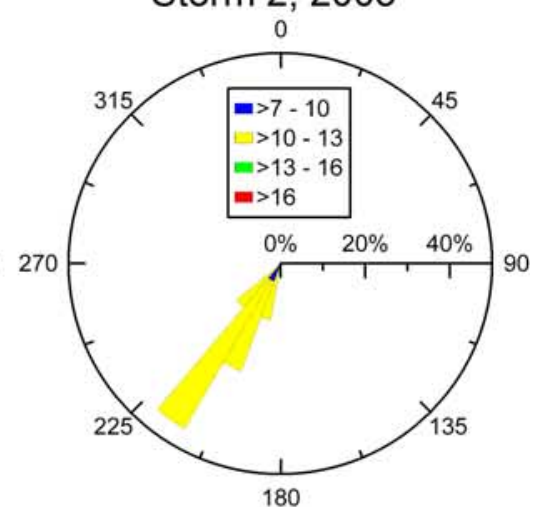

Storm 4, 2003

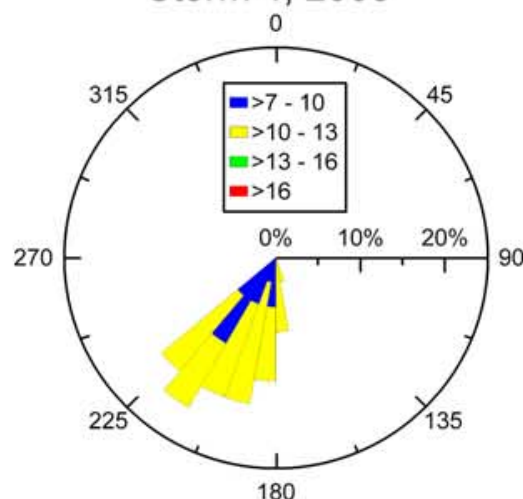

Storm 1, 2004

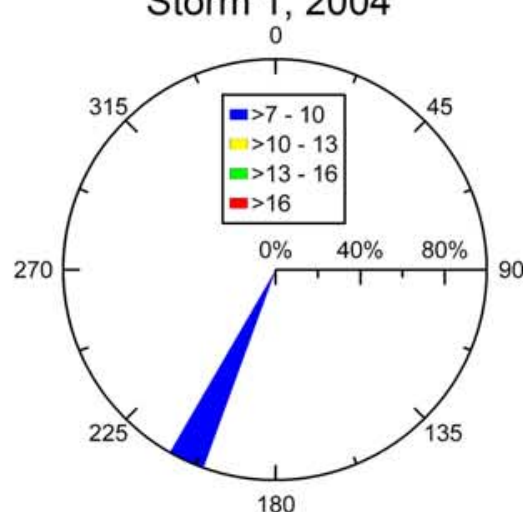

Storm 3, 2004

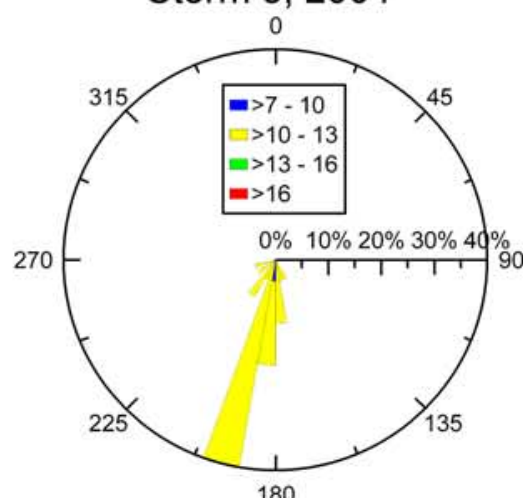

Figure 2. Wind roses for each storm, showing the frequency (\%), strength $\left(\mathrm{m} \mathrm{s}^{-1}\right)$, and direction of the prevailing wind at $14.9 \mathrm{~m}$ height. 
the domain for each 10-min time period through the course of the eight storms. Wind roses for each of the storms are shown in Figure 2. Sand flux at each location and time period was simulated using equation (4) and the velocities from QUIC at a height of $63 \mathrm{~cm}$. The direction of the sand flux was set to be the wind direction simulated by QUIC during the 10 -min sampling period at that location. In vector notation,

$$
\vec{q}=q \frac{\vec{U}}{|U|} .
$$

The scalar magnitudes of the sand flux, $q$, at each location were integrated with time (over the course of a storm) to show the locations where sand is moving (Figure 3 ). Within QUIC, the wind velocities are calculated at the center of grid cells. Consequently, the horizontal vectors representing the vertically integrated sand fluxes are also laterally at the centers of the QUIC grid cell coordinate system.

[22] The divergence of the flux $\left(\mathrm{g} \mathrm{cm}^{-2}\right.$ per time), or how much sand flux is entering and leaving a particular control volume, or $\mathrm{CV}$, was calculated using the vector sand fluxes and by assuming the conservation of mass. The rectangular grid system was redefined such that four sand flux vectors, $\vec{q}_{i, j}$, were located at the corners of each new grid CV. The total divergence of the flux of sand passing into (or leaving) each CV for every 10 -min time interval for a storm, $\nabla$. $\vec{q}_{i+1 / 2, j+1 / 2}$, was found by integrating the flux entering (or leaving) the $\mathrm{CV}$ through the walls, ceiling, and floor. For each of the four vertical faces of the CV, the flux component entering or leaving was found on the basis of averaging the normal components of the two vertically integrated flux values at the edges of the face (J. Burkardt, freeware Matlab programs "basis_q4.m" and "div_q4.m," 2006, available at http://www.csit.fsu.edu/ burkardt/m_src/ fempack/fempack.html). The flux components for each of the four faces were summed to get the net vertically integrated horizontal flux of sand passing into the $\mathrm{CV}$ through the vertical faces:

$$
\begin{aligned}
\nabla \cdot \vec{q}_{i+\frac{1}{2}, j+\frac{1}{2}}= & \frac{1}{2}\left\lfloor\left(\vec{q}_{i+1, j+1}+\vec{q}_{i+1, j}-\vec{q}_{i, j+1}-\vec{q}_{i, j}\right) \cdot \hat{i}\right. \\
& \left.+\left(\vec{q}_{i+1, j+1}+\vec{q}_{i, j+1}-\vec{q}_{i+1, j}-\vec{q}_{i, j}\right) \cdot \hat{j}\right\rfloor .
\end{aligned}
$$

[23] A net flux of sand passing into or out of CV through the four vertical faces represents a "convergence" or "divergence" of the flux, respectively. By mass conservation, a net flux of sand through the vertical faces of the CV equals the net flux through the floor of the $\mathrm{CV}$ (i.e., the desert surface) or through the ceiling. Here we assume that there is no sediment lost through the ceiling of the CV, so any net flux divergence through the vertical faces of the $\mathrm{CV}$ equals the net sediment flux through the floor of the CV. A convergence of flux through the faces leads to deposition of sand to the floor (a positive sedimentation rate), while a divergence implies erosion of the floor (a negative sedimentation rate). As with the flux magnitudes, the sedimentation rates for each 10-min time period were summed for the entire storm for each location (Figure 4). This shows the locations experiencing net erosion and deposition during the course of a storm.

[24] The sedimentation rate, defined as the change in soil mass on the floor of the control volume per time, can be used to calculate the average height loss (or gain) of the floor per time $\left(\frac{\delta \mathrm{h}}{\delta \mathrm{t}}\right)$. The total change in the height of the floor over a course of a storm equals the time-integrated sedimentation rate divided by density of the soil $\left(\rho_{\text {soil }}\right.$, empirically determined to be $1.6 \mathrm{~g} \mathrm{~cm}^{-3}$ [Gillette and Chen, 2001]). We calculated the lowering of the soil surface for the floor area of each $\mathrm{CV}$ within the study site for each of the 10 -min time periods for the eight storms.

[25] Because the simulated domain is finite in size, errors in both the flux and divergence patterns are present near the edges of the domain. These errors result from the lack of wake zones extending from dunes present in nature but not modeled in the simulated domain. Because the winds exclusively range from the south to west, a larger region of the domain $(8 \mathrm{~m}$, or a minimum of four times the height of the tallest simulated mesquite dune) was excluded on the south and west sides. A smaller area $(3 \mathrm{~m})$ in width was excluded along the north and east sides of the domain to minimize the errors associated with the smaller upwind effects of nonsimulated downwind dunes. Consequently, we define a "focus" area for analysis located between 8 and $57 \mathrm{~m}$ in both $x$ and $y$ directions to limit edge effect errors from unmodeled bushes.

\section{Results}

[26] Sand fluxes $\left(\mathrm{g} \mathrm{cm}^{-1}\right.$ per $\left.10 \mathrm{~min}\right)$ were calculated at $25 \mathrm{~cm}$ resolution throughout the domain for the duration of eight storms in 2003 and 2004. Figure 3 shows the flux magnitudes integrated over time for each of the eight storms. Sand flux magnitudes depend on location, with locations with high wind velocities correlated with high sand movement. Each location within the "focus" area had, on average, a flux of $2.1 \mathrm{~g} \mathrm{~cm}^{-1}$ per 10 min during the course of all storms studied. The open "streets" were the principal locations of substantial sand fluxes. The open areas downwind of dunes or bushes were mainly in wake flow and had very little, or zero, sand erosion. Including the area occupied by bushes and dunes (25\%), 34\% of the "focus" area had zero flux at all times during the eight storms.

[27] During a typical storm, the wind shifts from southerly to westerly, changing the wind velocity patterns within the domain. The sand flux patterns track these velocity changes. Each storm represents a sum of fluxes over many time periods with different wind directions and speeds. The intensity, direction, and duration of particular conditions varied between storms, resulting in differences in the integrated flux patterns. For storms with predominately southerly wind directions, high fluxes are found along one open area, or "street," between $x=30 \mathrm{~m}$ and $x=40 \mathrm{~m}$ (e.g., Figure 3, storms 1, 2, and 4, 2003). For storms with predominately westerly winds, high fluxes are found along the "street," found at $y=20 \mathrm{~m}$ (e.g., Figure 3, storms 3 and 5, 2003).

[28] When summed over time, the divergence of the flux $\left(\mathrm{g} \mathrm{cm}^{-2}\right)$ shows the locations of net sediment erosion and deposition within the domain (Figure 4). Deposition locations are usually found on the windward sides of the mesquite and coppice dune obstacles. Erosion locations are found within the streets, often near the upwind origins of the street. One such erosion location, common to nearly 

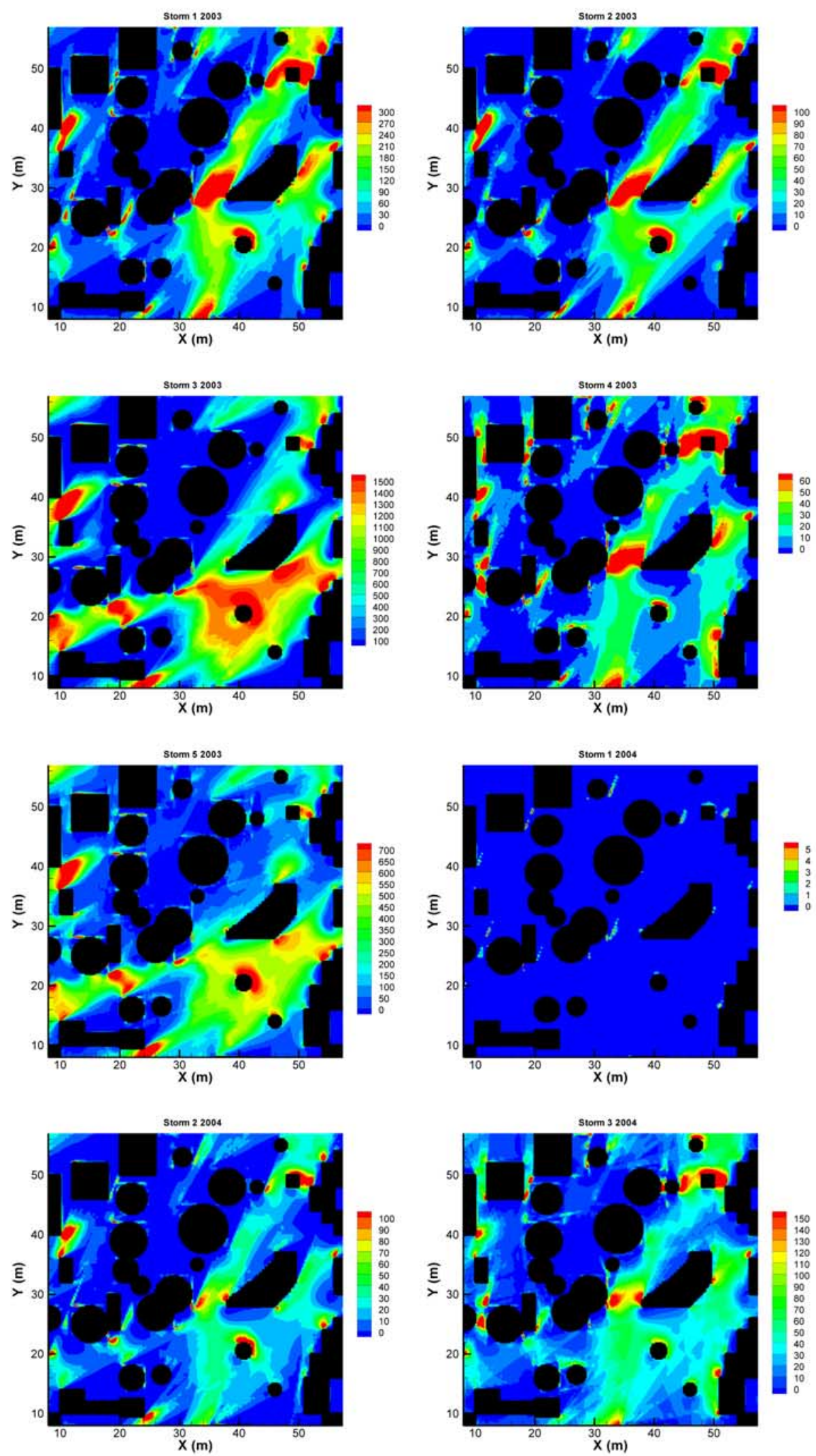

Figure 3. The net flux $\left(\mathrm{g} \mathrm{cm}^{-1}\right)$ within each grid cell calculated using the Kawamura [1964] equation for the entire study domain (between 8 and $57 \mathrm{~m}$ in both $x$ and $y$ ) summed over all 10-min increments for each of the eight storms. The mesquite bushes and dunes are black. Dark blue shows locations with no flux or very low flux, while red shows high-flux locations. 

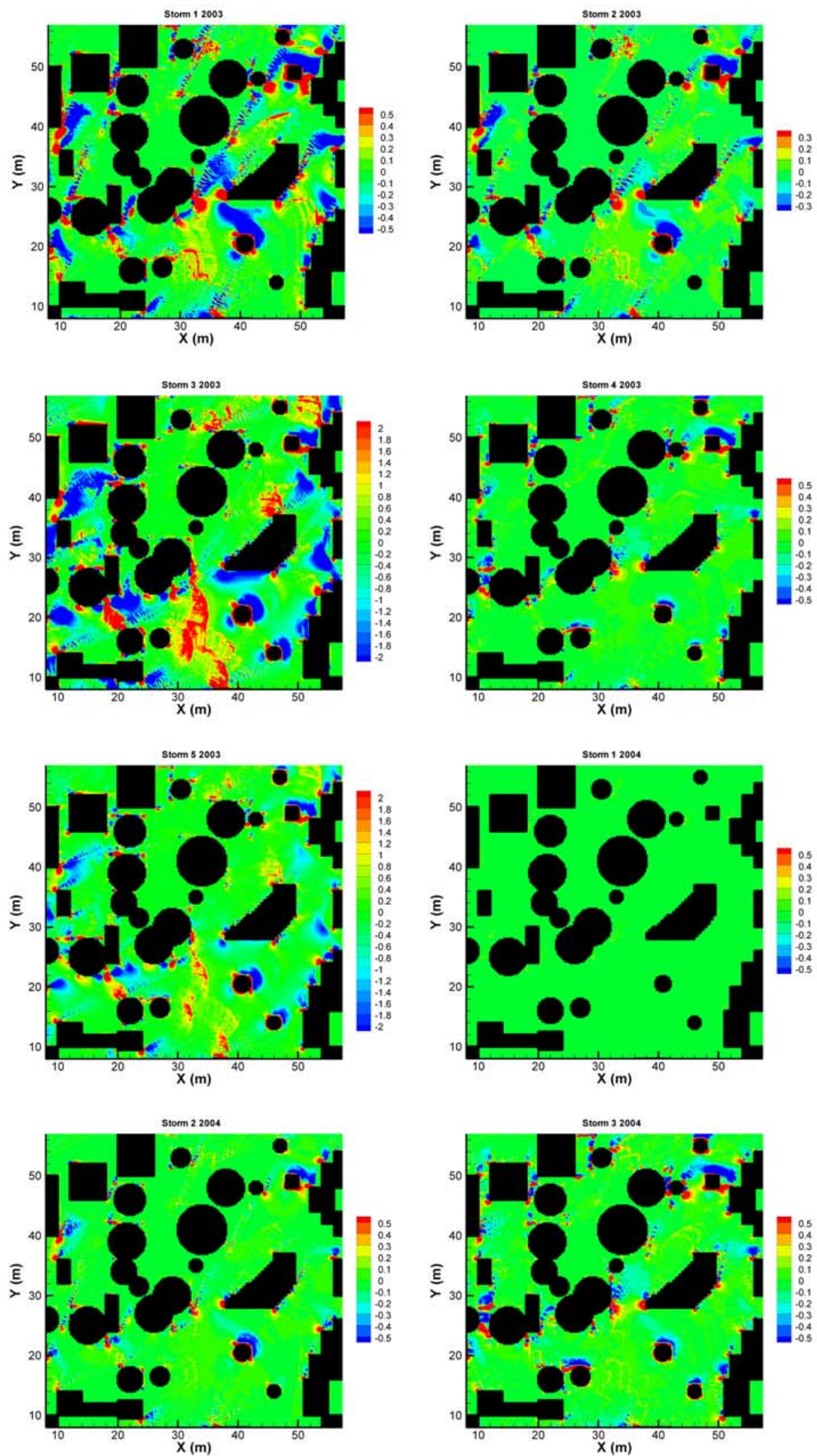

Figure 4. The net divergence of the flux $\left(\mathrm{g} \mathrm{cm}^{-2}\right)$ for each grid cell for the domain summed over all 10 -min increments for each of the eight storms. Locations experiencing erosion are red, locations experiencing deposition are blue, and locations experiencing no net sedimentation are green. The mesquite bushes and dunes are black. 
(a)

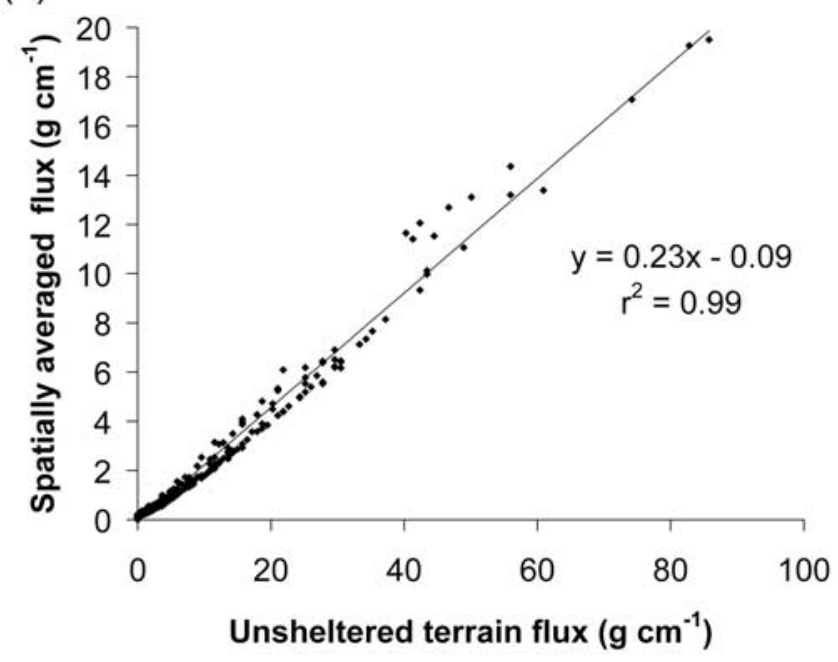

(b)

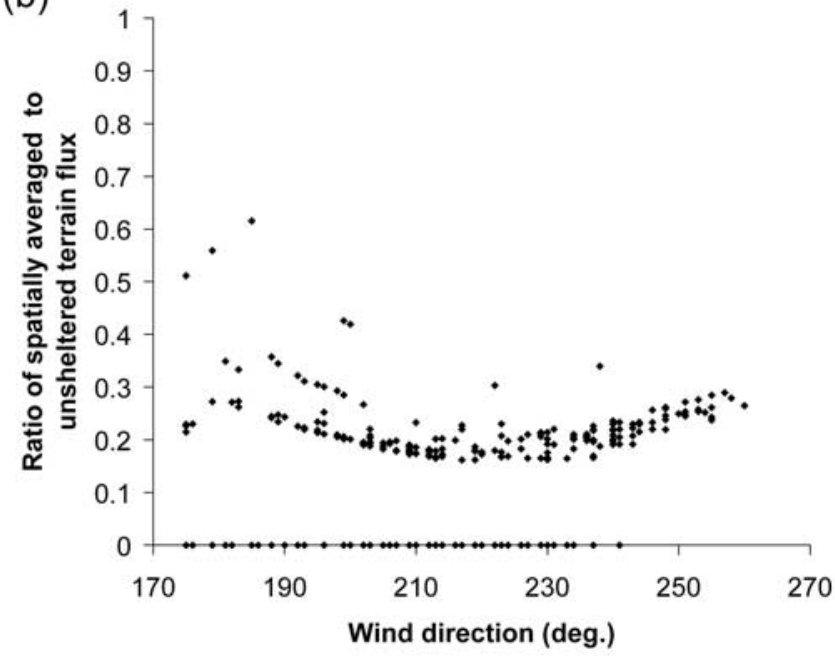

Figure 5. (a) The spatially averaged sediment flux $\left(\mathrm{g} \mathrm{cm}^{-1}\right.$ per $10 \mathrm{~min}$ ) modeled for the "focus area" as a function of the "unsheltered terrain" flux ( $\mathrm{g} \mathrm{cm}^{-1}$ per $10 \mathrm{~min}$ ) predicted using the reference logarithmic input boundary layer $\left(z_{0}\right.$ of $1.7 \mathrm{~cm}$ and reference wind speed at $14.9 \mathrm{~m}$ ) for open terrain. (b) The ratio of the spatially averaged flux to the "unsheltered terrain" flux as a function of wind direction (degrees). Points where the ratio is undefined (e.g., the "unsheltered terrain" flux is zero) are shown as zeros.

all the simulations, but particularly noticeable for the larger storms (e.g., storm 3, 2003) is found near coordinates $(32 \mathrm{~m}$, $20 \mathrm{~m}$ ) (Figure 4). Bowker et al. [2006, 2007] suggest that QUIC is not predicting as much acceleration of flow within the streets as found in the real-world. Therefore, the erosion along the central axes of the streets is likely underestimated in these simulations.

[29] Aside from the upwind street areas, erosion locations (shown in red in Figure 4) are often found on the lateral edges of the dunes. This is due to the acceleration of the flow as it passes around the obstacles. Since the obstacles are modeled with sharply defined edges, the acceleration of flow (and associated high velocities) around these objects is greater than expected around the aerodynamically rounded bushes/dunes found in nature. These areas are often associated with deposition areas immediately downwind as the flow returns to more normal conditions. Such large changes in erosion and deposition might show the mechanism forming the rounded nature of the dunes.

[30] As with both the velocity and flux patterns, the divergence of the flux patterns varied with the $14.9-\mathrm{m}$ wind velocity. Comparing the erosion patterns between storms (Figure 4), the vast majority of locations had a sedimentation rate near zero. Some of these locations (e.g., Figure 4, coordinates 26,40 ) had no erosion or deposition, regardless of the $14.9-\mathrm{m}$ wind velocity. However, some locations that experienced erosion for one wind direction experienced no erosion, or even deposition for others (Figure 4; compare storms 1 and 3 from 2003).

[31] For the "focus" area, the spatially averaged flux $\left(\mathrm{g} \mathrm{cm}^{-1}\right.$ per $\left.10 \mathrm{~min}\right)$ modeled in QUIC for each 10-min time period varied with the reference wind velocity, $U_{\text {ref }}$, and the wind direction. Since the flux is essentially proportional to the cube of the wind speed (equation (4)), the flux is sensitive to $U_{\text {ref }}$ with fluxes being quite high when $U_{\text {ref }}$ was larger than $15 \mathrm{~m} \mathrm{~s}^{-1}$.

[32] For each 10-min period, an "unsheltered terrain" sediment flux was calculated assuming the same logarithmic input boundary layer (and erosion constants) was present over a bare open area. The "unsheltered terrain" sediment flux was calculated using equation (4) and the wind speed at $63 \mathrm{~cm}$ taken from the input velocity gradient (defined using equation (1), the $\mathrm{U}_{\text {ref }}$ at $14.9 \mathrm{~m}$ for that time period, and a $\mathrm{z}_{0}$ of $1.7 \mathrm{~cm}$ ). The spatially averaged flux correlated well with the "unsheltered terrain" sediment flux averaging about a quarter of the magnitude (Figure 5). This is a direct result of the sheltering of the ground by the dunes. While the spatially averaged modeled flux appeared to correlate most closely with the "unsheltered terrain" sediment flux (and the reference wind speed), it had a dependence on wind direction (Figure $5 \mathrm{~b}$ ). For the range of wind directions modeled, the ratio of the spatially averaged flux to "unsheltered terrain" sediment flux had a minimum of about 0.18 at about $220^{\circ}$, and was higher $(\sim 0.3)$ for wind directions of about $180^{\circ}$ and $260^{\circ}$.

[33] The spatially averaged height of sediment change was found at each location in the "focus" area by summing the sedimentation rates over the course of a storm and dividing by the soil density $\left(1.6 \mathrm{~g} \mathrm{~cm}^{-3}\right.$ [Gillette and Chen, 2001]) For different storms, in deposition areas, the amount of average rise in the height of sediment "floor level" ranged between 0.04 to $0.81 \mathrm{~cm}$ while, for erosion locations the height of the sediment "floor level" fell between and 0.04 and $0.87 \mathrm{~cm}$ (Table 2). The high ends of these ranges are four times the measured yearly averages from Gibbens et al. [1983]. The simulated spatial and temporal (over a single storm) averages were certainly skewed by the extreme (and likely physically unrealistic) sedimentation rates found along some of the "sharp" edges of some of the rectangular block coppice dunes.

\section{Discussion and Conclusions}

[34] The production, transport, and deposition of windborne sediments are important factors in desert formation and 
evolution. The distributions of plants/dunes and the local wind patterns are interdependent. The distributions of plants affect the wind patterns and dune genesis, while the wind patterns affect seed dispersal patterns and where young plants are able to successfully germinate and survive. Furthermore, since the patterns and strength of the winds affect sediment erosion, and thus, aerosol dust production, understanding and predicting sediment erosion for desert areas with complex heterogeneous terrain is of major interest.

[35] Bowker et al. [2006, 2007] have shown that, with appropriate inputs and subsequent evaluation, the QUIC model can be used to predict the general airflow patterns and sediment flux in complex areas, such as the mesquite dune lands found in the northern Chihuahuan Desert in southern New Mexico. In this paper, we have applied this technique to simulate sediment flux at high spatial and temporal resolution for the entire study area for the duration of eight storms.

[36] The sand flux patterns are highly heterogeneous, changing with wind direction (Figure 3). The fluxes are high in the open "streets" while the fluxes are low in the wake areas downwind of large mesquite bushes and coppice dunes. There were large areas, including some open bare soil areas within the domain, that had very low, or zero, sand fluxes for all combinations of 14.9-m wind velocity. These areas were sheltered by the large dunes for the limited range of wind directions corresponding to high winds at the JER $\left(180^{\circ}-270^{\circ}\right)$. These simulations are consistent with field observations and measurements of sand flux [Gillette et al., 2006; Bowker et al., 2007].

[37] As the winds shift from southerly to westerly, the streets with high fluxes switch from the predominantly north-south orientation to those oriented east-west. The tight correlation of the spatially averaged modeled flux with the "unsheltered terrain" flux predicted using the reference wind speed suggests that for this range of wind directions $\left(180^{\circ}-270^{\circ}\right)$, flow can move through the domain relatively easily, channeling past the obstacles (Figure 5). The reference wind speed is clearly the first-order factor involved in wind erosion, though there was some dependency of the spatially averaged sediment flux with wind direction. This is seen as a variation (from about 0.18 to 0.3 ) in the ratio of the spatially averaged flux to the "unsheltered terrain" flux with wind direction (Figure 5b). Possible reasons for the minimum at about $220^{\circ}$ include increased sheltering of the surface due to the dunes and decreased channeling of flow along the streets. Wind roses at the Jornada site show that the sediment eroding winds occur in the direction interval between $180^{\circ}$ and $270^{\circ}$ for April 2003 and 2004 [Gillette et al., 2006] (Figure 2). We expect that for wind directions roughly perpendicular to the orientation of the streets (e.g., southeasterly winds, $120^{\circ}$ ), substantially decreased fluxes would be found (and simulated), because of an increase in the area experiencing wake flow.

[38] By calculating the divergence of the flux and setting it equal to the net vertical flux of sand mass from the ground, we predicted the locations and magnitudes of sediment erosion and deposition (Figure 4). The patterns vary with the reference wind velocity, but, generally, show that sediments are eroding from the streets and are depositing on downwind dunes [Gillette and Pitchford, 2004; Okin and Gillette, 2001; Gillette et al., 2006]. On the basis of some differences in predictions and measurements of flow acceleration within the streets, we expect that the locations of erosion may be somewhat broader than simulated, starting at the origin of the street and extending from the central street areas along the length of the street, rather than being focused at the origin of the street [Bowker et al., 2006].

[39] As expected, the divergence patterns suggest that the sediment from the streets is depositing on downwind mesquite bushes and coppice dunes. The simulations show much of the sediment is deposited at the dune interface and the surrounding cells on the windward sides of the dunes (Figure 4). Deposition occurs as the flow and (sediment flux) converges as it encounters the "upwind cavity" and slows down. Clearly, this deposited sediment will contribute to dune formation and growth. However, we expect that, in nature, the sediment is actually blown into the bushes and behind the dunes in a manner consistent with field observations of dune formation showing growth in the lee of the dune, rather than on the frontal edge. Since the dunes and bushes simulated in QUIC are solid, with no internal flow, no sediment deposition can occur within the bushes and dunes. Similarly, deposition cannot occur within the wake zone of the dunes because there is a divergence of the flux (rather than the expected convergence) as it transitions from the zero flow/flux condition within the bushes to the slow flow (usually below threshold) within the wake zones. We expect that, through processes not simulated in QUIC (flow within the bushes, and sediment depositing in the wake), the sediments predicted by QUIC to deposit on the windward side of the dunes should be deposited within and behind the dunes.

[40] Using the totals of the flux divergence to calculate the rise or fall of the sediment level, averaged across locations, permits comparison with field measurements [Gibbens et al., 1983]. Generally, we expect that the vast majority of the sediment eroded is deposited within the domain. Sediment mass lost from the system includes the aerosol dust production rate, which is around $5 \times$ $10^{-7} \mathrm{~cm}^{-1}$ multiplied by the average airborne sediment flux (2.1 $\mathrm{g} \mathrm{cm}^{-1}$ per $\left.10 \mathrm{~min}\right)$ [Gillette et al., 2004]. On average, this rate of $1.1 \times 10^{-6} \mathrm{~g} \mathrm{~cm}^{-2}$ per $10 \mathrm{~min}$, multiplied by the total time of the storms in April 2003 and 2004 (297 10-min periods) for a total dust flux loss of $3.1 \times 10^{-4} \mathrm{~g} \mathrm{~cm}^{-2}$. This is a negligible amount for calculations of soil redistribution and estimations of dune growth.

[41] Making a qualitative comparison between the longterm yearly average sediment deposition and deflation measurements [Gibbens et al., 1983] with the predictions derived from time-resolved QUIC velocity/sand flux simulations from the intensive spring storms in April for 2 years, we find similarities (Table 2). However, since the 2 years we modeled were not from the same time period and may not be representative of the average meteorological conditions over the 45-year period, and the fact that the overall condition of the environment significantly changed (with the dunes forming) over the 45-year period, quantitative comparisons are difficult to make.

[42] On the basis of our simulations showing nearly four times the average yearly deflation value from just one storm (storm 3, 2003, which was one of the largest storms on record), our simulations may be overestimating the sediment movement. One possibility for overestimation may be 
attributable to the rectangular geometry of some the roughness elements within QUIC. Large wind velocities, and thus large fluxes and sedimentation rates are found as the flow separates at the sharp edges of these blocks (Figures 3 and 4). The values may skew the spatially averaged sedimentation rates, leading to an overestimation of the average sediment rise and fall.

[43] Furthermore, in the sediment height change calculations, we did not include the area ( $\sim 50 \%$ of the total area) experiencing zero sedimentation in the erosion and deposition averages. Gibbens et al. [1983] found that all areas experienced some change. Consequently, for proper comparison, the zero sedimentation rate area from our simulations should be included in the spatial averages. However, it is not clear how best to allocate this area for proper comparison. Dunes/bushes are likely areas of deposition (accounting for half of the zero-flux area, and 25\% of the total area) and probably should be added to the $\sim 30 \%$ of the domain (predicted by QUIC) experiencing deposition. The remaining area experiencing zero flux $(\sim 25 \%$ of the total area) probably should be included in the region of deflation.

[44] In conclusion, we suggest that the exact locations of deposition and erosion may not be exactly consistent with what is observed in nature, but the general locations (e.g., streets for erosion, and dunes for deposition) and magnitude of the deposition patterns may be representative. Hence, it would be possible to predict dune formation and gain understanding as to some of the causes of plant distributions within the desert. For example, starting with a few randomly placed small plants, and determining the locations of high erosion (likely to not be places of successful plant survival and coppice dune formation), it would be possible to predict where plants might succeed and where dunes would grow. As the dunes grow and their wake zones enlarge, some of these erosion areas may be transformed into sheltered areas where plants and dunes could grow. It would be interesting to determine under what conditions (e.g., winds are predominately from a limited direction) such a system would transform itself into a system of oriented streets and dunes. Potential challenges include understanding how to dynamically adjust the input boundary layer in QUIC to account for the roughness changes in the domain as the size and distribution bushes and dunes change. Furthermore, a predictive model, such as QUIC, could be used to evaluate and optimize the geometries and placement of fences and vegetation barriers designed to prevent or augment windbased erosion.

[45] This study site is a small representative area within the larger (and morphologically similar) mesquite dune land desert region. Extending the high-resolution simulation of wind velocity and sediment flux to a larger region, effectively modeling the locations of sediment production, transport, and deposition could provide insight into the effects of wind on shaping the desert and the production of dust aerosols at a regional level.

[46] Acknowledgments. Ashok Patel carefully carried out model runs. Steve Perry and Jenise Swall discussed our data and offered helpful insights. The research presented here was performed under the Memorandum of Understanding between the U.S. Environmental Protection Agency (EPA) and the U.S. Department of Commerce's National Oceanic and
Atmospheric Administration (NOAA) and under agreement DW13921548. This work constitutes a contribution to the NOAA Air Quality Program. Although it has been reviewed by EPA and NOAA and approved for publication, it does not necessarily reflect their policies or views.

\section{References}

Andreae, M. O. (1996), Raising dust in the greenhouse, Nature, 380, $389-390$.

Bagnold, R. A. (1941), The Physics of Blown Sand and Desert Dunes, 265 pp., CRC Press, Boca Raton, Fla.

Bowker, G. E., D. A. Gillette, G. Bergametti, and B. Marticorena (2006), Modeling flow patterns in a small vegetated area in the northern Chihuahuan Desert using QUIC (Quick Urban \& Industrial Complex), Environ. Fluid Mech., 6, 359-384, doi:10.1007/s10652-005-6021-8.

Bowker, G. E., D. A. Gillette, G. Bergametti, B. Marticorena, and D. K. Heist (2007), Sand flux simulations at a small scale over a heterogeneous mesquite area of the northern Chihuahuan Desert, J. Appl. Meteorol., 46, $1410-1422$.

Fackrell, J. E. (1984), Parameters characterising dispersion in the nearwakes of buildings, J. Wind Eng. Ind. Aerodyn., 16, 97-118.

Gibbens, R. P., J. M. Tromble, J. T. Hennessy, and M. Cardenas (1983), Soil movement in mesquite dunelands and former grasslands of southern New Mexico from 1933 to 1980, J. Range Manage, $36(2), 145-148$

Gillette, D. A. (1981), Production of dust that may be carried great distances, in Desert Dust: Origin, Characteristics, and Effect on Man, edited by T. L. Pewe, Geol. Soc. Am. Spec. Pap., 186, 11-26.

Gillette, D. A., and W. Chen (2001), Particle production and aeolian transport from a "supply-limited" source area in the Chihuahuan Desert, New Mexico, United States, J. Geophys. Res., 106(D6), 52675278 .

Gillette, D. A., and A. M. Pitchford (2004), Sand flux in the northern Chihuahuan Desert, New Mexico, USA, and the influence of mesquitedominated landscapes, J. Geophys. Res., 109, F04003, doi:10.1029/ 2003JF000031.

Gillette, D., D. Ono, and K. Richmond (2004), A combined modeling and measurement technique for estimating windblown dust emissions at Owens (dry) Lake, California, J. Geophys. Res., 109, F01003, doi:10.1029/2003JF000025.

Gillette, D. A., J. E. Herrick, and G. A. Herbert (2006), Wind characteristics of mesquite streets in the northern Chihuahuan Desert, New Mexico, USA, Environ. Fluid Mech., 6, 241-275.

Hosker, R. P., Jr. (1984), Flow and diffusion near obstacles, in Atmospheric Science and Power Production, edited by D. Randerson, pp. 241-326, U.S. Dep. of Energy, Washington, D. C.

Kawamura, R. (1951), Study of sand movement by wind (in Japanese), Rep. Inst. Sci. Technol., 5, pp. 95-112, Univ. of Tokyo, Tokyo.

Kawamura, R. (1964), Study of sand movement by wind, Hydraul. Eng. Lab. Rep. HEL 2-8, 58 pp., Univ. of Calif., Berkeley, Calif.

Marticorena, B., and G. Bergametti (1995), Modeling the atmospheric dust cycle: 1. Design of a soil-derived dust emission scheme, J. Geophys. Res., 100(D8), 16,415-16,430.

Marticorena, B., G. Bergametti, B. Aumont, Y. Callot, C. N'Doumé, and M. Legrand (1997), Modeling the atmospheric dust cycle: 2 . Simulation of Saharan dust sources, J. Geophys. Res., 102(D4), 4387-4404.

Okin, G. S., and D. A. Gillette (2001), Distribution of vegetation in winddominated landscapes: Implications for wind erosion modeling and landscape processes, J. Geophys. Res., 106(D9), 9673-9683.

Okin, G. S., D. A. Gillette, and J. E. Herrick (2006), Multi-scale controls on and consequences of aeolian processes in landscape change in arid and semi-arid environments, J. Arid Environ., 65, 253-275.

Owen, P. R. (1964), Saltation of uniform grains in air, J. Fluid Mech., 20, $225-242$.

Pardyjak, E., and M. Brown (2001), Evaluation of a fast-response urban wind model-Comparison to single-building wind-tunnel data, Rep. LA-UR-01-4028, 6 pp., Los Alamos Natl. Lab., N. M.

Pardyjak, E., and M. Brown (2002), Fast response modeling of a two building urban street canyon, Rep. LA-UR-02-1217, Los Alamos Natl. Lab., N. M.

Pardyjak, E., and M. Brown (2003), QUIC-URB v1.1: Theory and user's guide, Los Alamos Natl. Lab., Los Alamos, N. M.

Pardyjak, E. R., M. J. Brown, and N. L. Bagal (2004), Improved velocity deficit parameterizations for a fast response urban wind model, paper presented at 84th AMS Conference: Modeling Urban Land Surfaces and Buildings: Part 2, Am. Meteorol. Soc., Seattle, Wash., Jan.

Priestly, C. H. B. (1959), Turbulent Transfer in the Lower Atmosphere, Univ. of Chicago Press, Chicago, Ill. 
Röckle, R. (1990), Bestimmung der Stomungsverhaltnisse im Bereich Komplexer Bebauugsstrukturen, Ph.D. dissertation, Fachber. Mech., Tech. Hochsch. Darmstadt, Darmstadt, Germany.

Schlesinger, W. H., J. F. Reynolds, G. L. Cunningham, L. F. Huenneke, W. M. Jarrell, R. A. Virginia, and W. G. Whitford (1990), Biological feedbacks in global desertification, Science, 247, 1043-1048.

White, B. R. (1979), Soil transport by wind on Mars, J. Geophys. Res., 84(B8), 4643-4651.

Williams, M., M. Brown, B. Singh, and D. Boswell (2004), QUIC-PLUME theory guide, Rep. LA-UR-04-0516, Los Alamos Natl. Lab., N. M.

G. Bergametti and B. Marticorena, UMR 7583, Laboratoire Interuniversitaire des Systèmes Atmosphériques, CNRS, Universités Paris 7-Paris 12, Créteil F-94010, France.
G. E. Bowker, Clean Air Markets Division, U.S. Environmental Protection Agency, 1200 Pennsylvania Avenue, NW, Washington, DC 20460, USA. (bowker.george@epa.gov)

D. A. Gillette and D. K. Heist, Atmospheric Science Modeling Division, Air Resources Laboratory, National Oceanic and Atmospheric Administration, Research Triangle Park, NC 27711, USA. 